\title{
Socialization of Zoom Application Utilization for Making a Learning Presentation in Video Form
}

\author{
RETNA NINGSIH, DEWI MUSTARI, REKO SYARIF HIDAYATULLOH \\ Universitas Indraprasta PGRI, Jakarta \\ Email: ennatatto@gmail.com
}

Received 10 September 2021 | Revised 22 November 2021 | Accepted 28 November 2021

\begin{abstract}
Learning is a process of student interaction with teachers and learning resources in a learning environment. The article clearly states that learning is a process of interaction between teachers (educators) and students (students). During this pandemic, all learning processes are carried out remotely. Because face-to-face learning in class cannot be carried out as a result of the highly contagious corona virus outbreak. The selection of the right learning media must pay attention to and adjust the needs of the subject matter so that the media functions as a tool that can increase understanding and interest in learning. Zooming presentation learning media is one of the newest applications that has a fresh, unique, attractive appearance and has sophistication in zooming in and out and can combine videos, images and animations. With this community service, it is hoped that it can help the problems of teachers at Darul Faizin High School regarding online learning problems. So that this socialization can be a solution in providing learning materials to students.
\end{abstract}

Keywords: Zoom; Learning; Pandemic

\section{INTRODUCTION}

The government implements social distancing policies and physical distancing in all fields, including education. Social distancing is a term to reduce large crowds, maintain distance, and leave gatherings (Setiani, 2020). This condition gave rise to new terms, namely work from home, study at home, and teach from home. In the field of education, the form of social distancing is by implementing distance learning (PJJ) where learning activities are no longer carried out in buildings (schools or campuses), learning activities are carried out from home online (in a network) (Marbun, 2021). In online learning technology has an important role to support the learning process (communication interaction between educators and students).

Distance learning (PJJ) as one of the impacts of covid-19 has unconsciously changed the concepts, methods, and designs of learning that are already underway (Marbun, 2021). Before the learning pandemic took place conventionally, which was teacher-centered, during the pandemic, educators had to be innovative in designing student-centered learning. This 
online learning forces educators to develop their competence in the field of technology, educators find it difficult to provide an objective assessment. For students, they are still unable to adapt to online learning because they are accustomed to face-to-face meetings and the unavailability of supporting facilities and infrastructure in the homes of each student. For parents, online learning has the effect of increasing the cost of purchasing data packages or paying internet bills.

Distance learning (PJJ) has been going on for approximately 2 semesters, namely the beginning of the even semester of 2020 and the odd semester of 2021. Distance learning (PJJ) is carried out using online learning methods. Online learning is carried out not limited by space, learning is combined with the internet (virtual classroom), learning in cyberspace (Rosyid, Thohari, \& Lismanda, 2020). During this time, the obstacles to online learning began to be resolved. Educators are getting used to preparing online learning with more interesting learning innovations, educators are familiar with the applications used in online learning. The school carries out coaching as an effort to develop the competence of educators. Good teacher performance will affect the quality of learning. Students have begun to adapt well in accordance with Sadikin's statement that distance learning (PJJ) with this online system is able to foster independent learning (Sadikin \& Hamidah, 2020). For parents, the monthly expenditure for purchasing internet quota has begun to be budgeted, the government also provides internet quota package assistance for educators and students.

Learning is a process of student interaction with teachers and learning resources in a learning environment. The article clearly states that learning is a process of interaction between teachers (educators) and students (students). In this learning there is an effort to create conditions for learning activities to occur, which shows students' efforts to learn teaching materials as a result of teacher treatment (Nur, 2020). During this pandemic, all learning processes are carried out remotely. Because face-to-face learning in class cannot be carried out as a result of the highly contagious corona virus outbreak. So like it or not, learning is done online. Teachers can use various applications that can help in the teaching and learning process. However, the teacher must also consider all possibilities or constraints when determining the application to be used as a learning medium. Learning according to UNESCO in 1997 revealed that learning is based on four main pillars (The Four Pillars of Education). The four main pillars include, learning to know (Learning to know), learning to work (Learning to do), learning to develop as a whole (Learning to be) and learning to live together (Learning to live together). This is a philosophical aspect that must be applied in carrying out the learning process (Putri et al, 2020).

Learning requires interaction, this shows that the learning process is a communication process, meaning that the teaching and learning process occurs in the process of delivering messages from the source of the message to the recipient of the message (Sadiman et al, 1986). The selection of the right learning media must pay attention to and adjust the needs of the subject matter so that the media functions as a tool that can increase understanding and interest in learning. One of them is by using zooming presentation learning media, which is in line with Artem's research by using a zooming presentation to present interactive explanations in learning (Pecheny, 2010). Zooming presentation learning media is one of the newest applications that has a fresh, unique, attractive appearance and has sophistication in zooming in and out and can combine videos, images and animations. So that our community service team at Indraprasta PGRI University will provide socialization to teachers at Darul Faizi High School about making presentations using zoom. Because until 
now in March 2021 learning is still being done online. The obstacles in online learning such as:

1. The location of the house is not covered by the internet network, including limited student internet quotas,

2. The learning media used by the teachers is dominantly monotonous and makes the students feel bored or bored,

3. The character or behavior of students is difficult to monitor,

4. Less effective delivery of material only in the form of ppt,

5. The assignments given by the students are piled up.

6. Absorption of subject matter is very limited due to lack of material exposure,

7. Most of the teachers who do not really understand about learning media so that the learning media only uses WAG.

The main challenge to doing a virtual presentation is that you can't see your audience in real life. Likewise, they can't see you in person anyway. However, one thing you can feel is that they can easily become uninvolved with your presentation, due to various distractions (Erry, 2020). Teachers quickly learn various applications that can help to transfer material or give instructions for learning activities including assignment submission and assignment collection (Riyadii, 2020). The Zoom application is usually used for online meeting activities, so the teachers are already familiar with the application, one of the facilities is a recording button that can record the course of the event. The targets of this community service are:

1. With the socialization regarding the use of the zoom application as an online learning medium, it can increase the knowledge of teachers in using the application.

2. Provide knowledge about the ease of use of the zoom application as a supporter in online learning.

The outputs resulting from this community service are:

1. Improving the competence of teachers in the use of the zoom application as a learning medium.

2. Improve the teacher's ability to make presentation videos using the zoom application.

\section{METODH}

The way that has been agreed and taken is by providing socialization to teachers at Darul Faizin High School online, namely using the Zoom application as a medium for community service today. Socialization about using zoom application for making learning videos. Community service at Darul Faizin High School using a socialization approach. This approach allows the participants to directly understand the training materials provided by the implementing team from Indraprasta PGRI University. On this occasion, the participants, namely teachers at SMA Darul Faizin, learned how to use the zoom application to make good learning videos.

1. The implementation of this activity is carried out in three stages, namely the preparation, implementation and evaluation stages.

2. Preparation Stage At this stage the team conducts a preliminary survey to determine the condition of the target activity by analyzing the condition of the place to be used, the condition of the participants who will be given treatment and preparing a plan for the activities to be carried out. The next stage of preparation, the team prepares the 
3. materials that will be used as presentation materials. And for now the socialization is done online.

4. Implementation stage, namely, the implementing team conducted socialization regarding the use and use of the zoom application as a learning medium and for making presentation videos which could later be uploaded on YouTube, to make it easier for students to access the material.

5. Evaluation is carried out to measure the level of success of an implementation activity from the use of the zoom application as an interactive learning medium,

\section{RESULT AND DISCUSSION}

Through the Ministry of Education and Culture to address this, the Government has issued a ban for all levels of education to carry out face-to-face learning directly in classrooms and urges every school to carry out online or online learning (Marsiding, 2021). In this unexpected situation, conditions have forced all elements of education including classroom teachers to think about how to change and prepare the learning process for students who previously used the face-to-face method to become an online learning model held at their respective homes. In today's era, many say learning is easy and can be from anywhere. Yes, yes, now there are so many platforms for online learning. Often, online learning platforms or courses, such as Udemy, feature videos for trail learning. It turns out, making learning videos is easy to do. We can make learning videos with Zoom. Following the materials of this community service, that is steps to make a learning video using the zoom application that shown at figure 1 to 7 (Ainun, 2020):

1. To make learning videos with the Zoom application, of course we must first install the Zoom application. After that open the Zoom application and login.

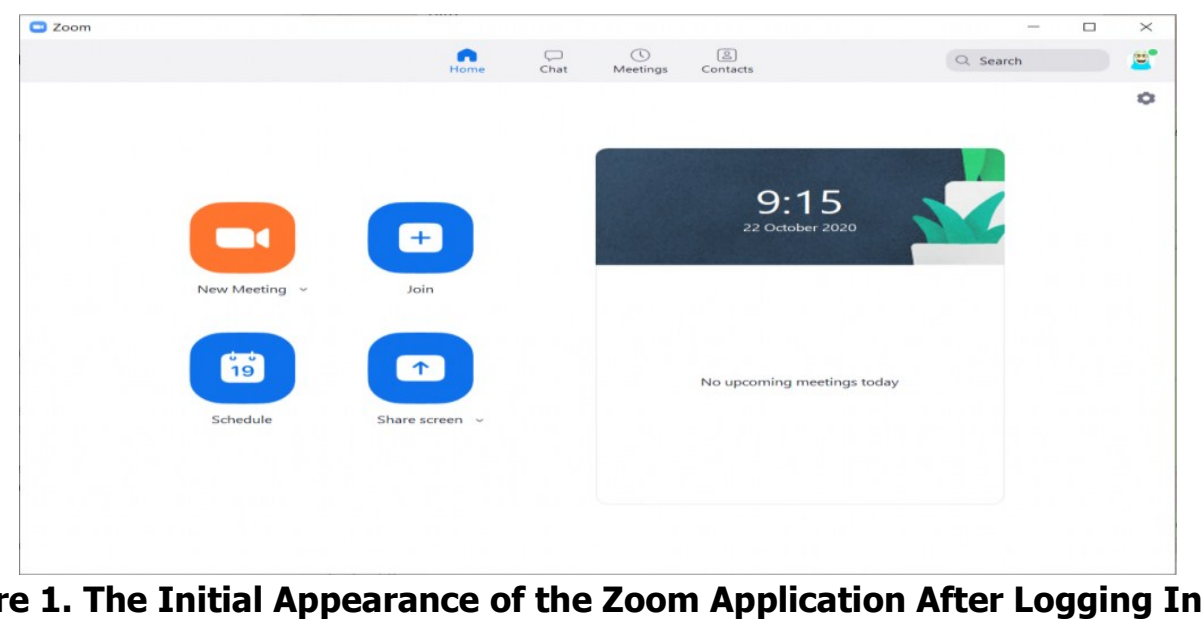

Figure 1. The Initial Appearance of the Zoom Application After Logging In

2. Preparing learning materials, So, I need to open a browser to access the learning materials that I have prepared. 

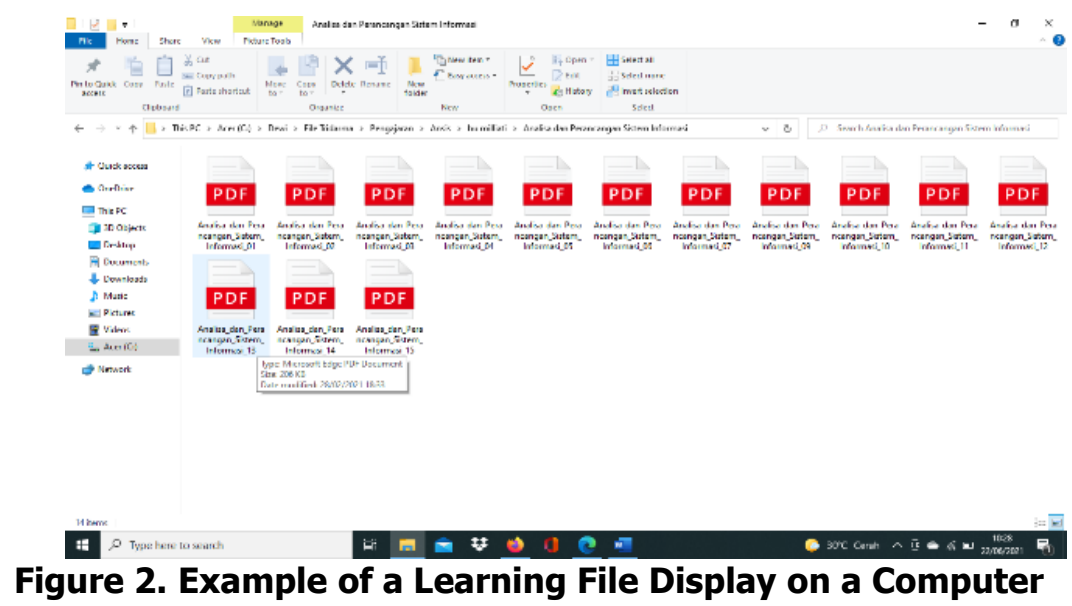

3. Click New Meeting to Zoom Application

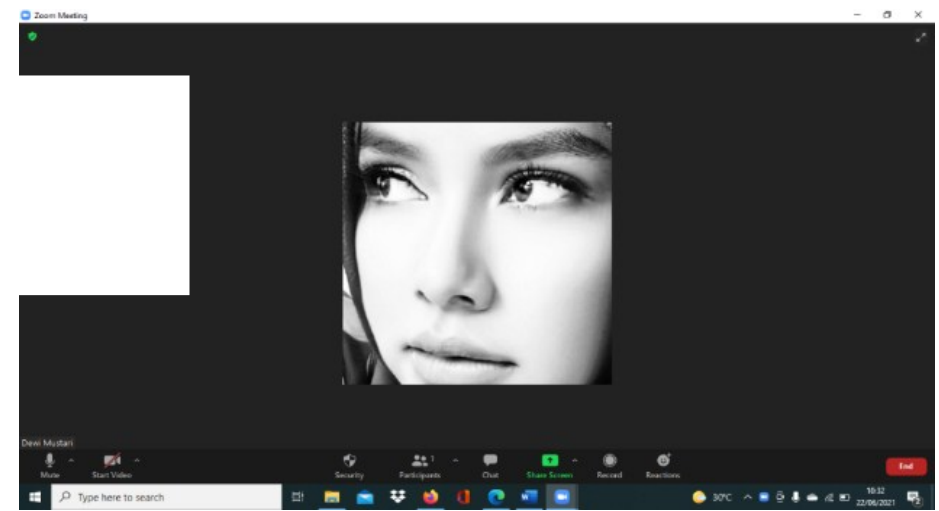

Figure 3. Start the Meeting Process, Make Sure the Voice Can Enter Clearly

In the initial view of the Zoom application, we can select New Meeting. After that, make sure our voice comes in / is heard. This is the condition I use the background but turn on the video.

4. Click Record to Start Recording

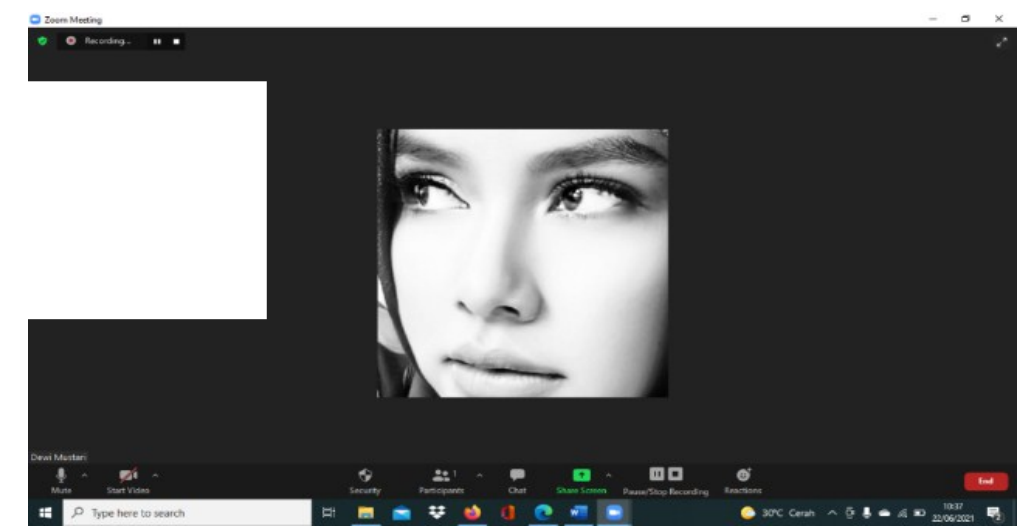

Figure 4. To Start Recording, We Have to Click the Record Button

To start recording, we just click the Record button at the bottom of the Zoom application screen. For example, in between recordings we want to pause, we can press the Pause button later. When finished recording, we can press the Stop button. 
5. Share Screen of Learning Materials to be Delivered

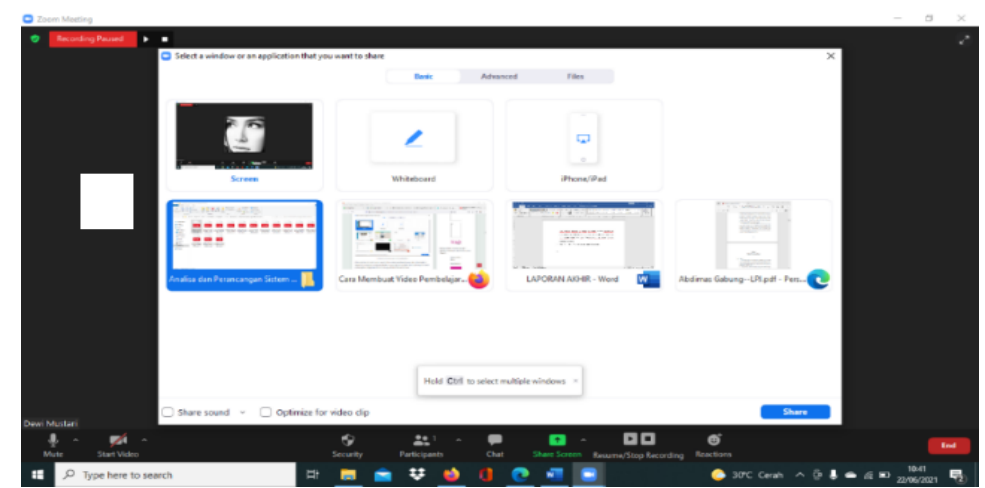

Figure 5. Share Screen on Learning Materials

Click the Share Screen button to display the learning material to be delivered. After that, convey the learning material that you want to convey. If you want to change learning materials, just click share screen again to choose another screen. After completing the material to be conveyed, we can stop the share screen by stopping the Share Screen.

\section{End Meeting to Save Record}

To close the learning video recording, we can click Stop Recording. After the recording is stopped, the video will not automatically be saved. To save it, we must finish the meeting first by clicking End Meeting. Once End Meeting is selected, Zoom automatically returns to the initial view. However, there is information regarding converting meeting recording as information on storing the video that we just recorded.

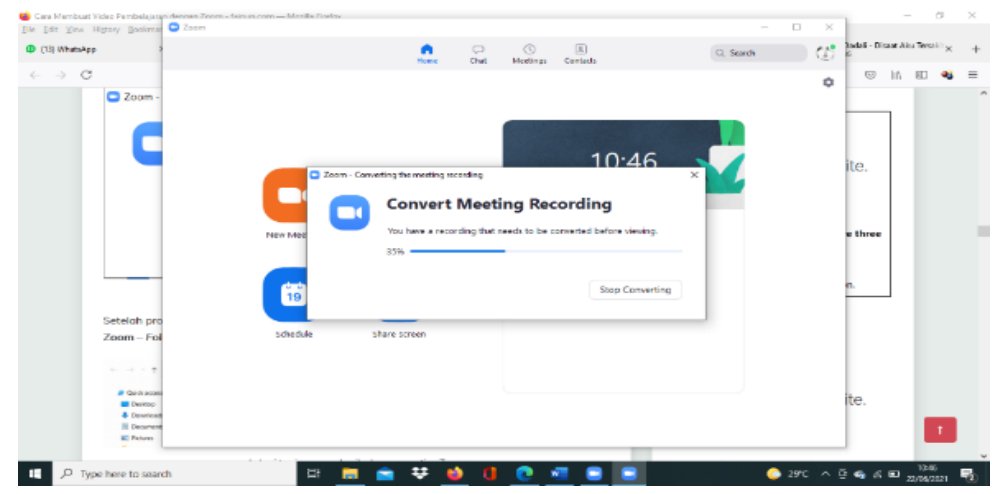

Figure 6. The Recording is Converted by Zoom After the Meeting is Over

After the converting process is complete, we can access the video files in File Explorer: Documents - Zoom - Meeting Folder according to the date and time. 


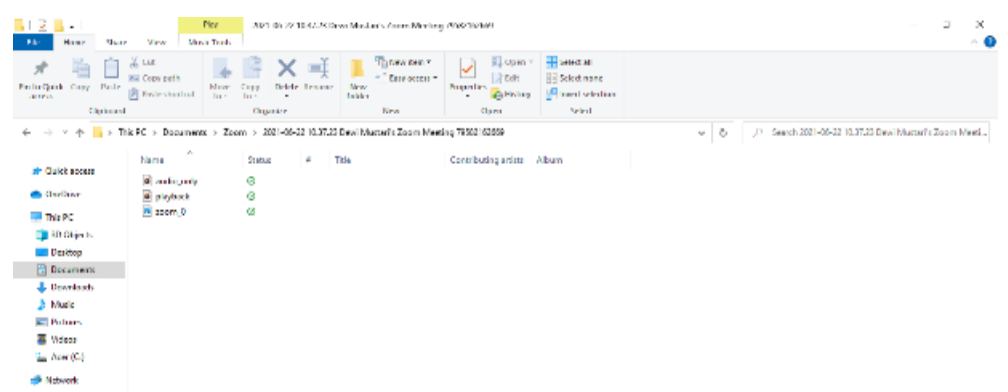

\section{Figure 7. The Location Where the Recording of the Zoom Meeting is Stored}

\section{Community Service Documentation}

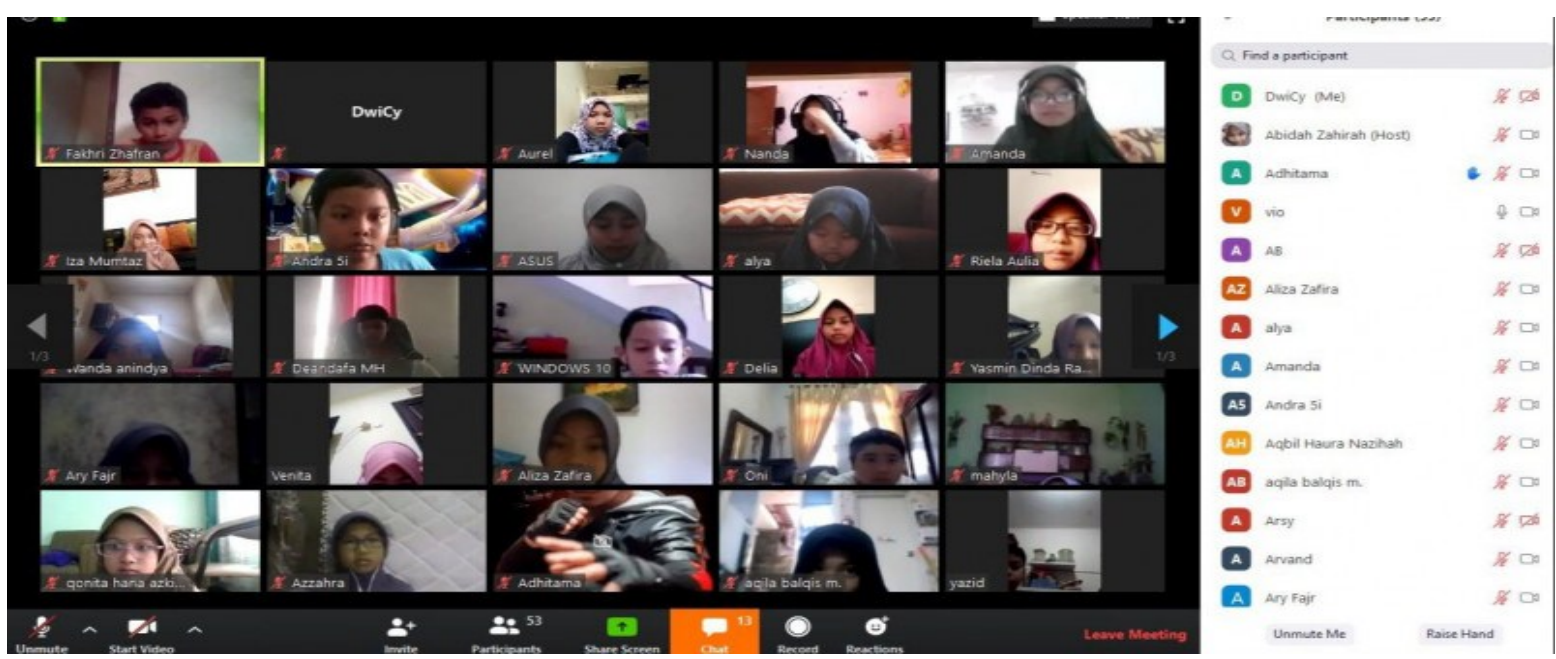

Figure 8. Documentation of the Community Service

Distance learning (PJJ) by utilizing the Zoom application makes it easy for educators and students to interact directly even though there are distance limitations. The Zoom application is one of the online learning media that allows the delivery of subject matter to students. In the Zoom application, educators can communicate directly with students via video. Educators can also take advantage of the share screen feature to display subject matter or learning videos. The Zoom application can record all learning activities in an unlimited time if using a paid account. Online learning media as an alternative to electronic-based learning provides many benefits, especially in this pandemic condition, which does not allow face-to-face learning processes. Figure 8 shows documentation of the community service.

In the online learning process using the Zoom application, educators are the main actors who plan, direct, and carry out these activities. Educators have the same demands even though learning is done online, namely teaching, guiding, and fostering students. In the process, educators must make rules when online learning takes place, such as students must wear school uniforms when studying online, students must activate their cameras so that educators can see directly what students are doing, students turn off the sound button so that noise does not occur when The teacher explains the subject matter, students can activate the voice button if students want to ask questions. Educators must always remind 
students that when learning takes place they are less focused, educators create a productive two-way communication atmosphere so that learning is more interesting and not monotonous.

With the implementation of community service activities, namely the socialization of the use of the zoom application to make learning videos, the results obtained from the socialization are as follows:

1. Teachers at Darul Faizin High School can use the Zoom application as a teaching medium to make learning videos.

2. With the socialization of community service regarding the use of the Zoom application as a learning medium, it can help teachers in the teaching and learning process using videos that can be uploaded to YouTube. So that students can access learning materials whenever needed.

3. The enthusiasm of the teachers is very high for providing material on how to make learning videos using zoom.

4. The team also applies the results of the implementation of this community service activity in the form of a draft PKM journal article and hopes to be published in an accredited PKM journal.

\section{CONCLUSIONS}

From the community service activities that have been carried out by the team, the following conclusions can be drawn. With this community service, it is hoped that it can help the problems of teachers at Darul Faizin High School regarding online learning problems. So that this socialization can be a solution in providing learning materials to students. With this community service, of course we hope that teachers can use technology as a solution to the problems faced in terms of online learning. Community service that is being carried out at this time so that the results can be monitored, the teachers are the objects of achievement after the team carries out community service.

\section{LIST OF REFERENCES}

Ainun, Syahri MS. (2020). Hubungan Gaya Hidup dengan Kejadian Hipertensi pada Mahasiswa di Lingkup Kesehatan Universitas Hasanuddin. [Skripsi IImiah].

Erry Y., M., S. M. (2020). Asupan Gizi dalam Upaya Meningkatkan Imunitas di Masa Pandemi Covid-19. Jurnal Kesehatan, 1.

Marsiding, Z. (2021). Efektifitas Penggunaan Media Zoom Terhadap Pembelajaran Pada Masa Pandemi Covid-19. Jurnal IImiah Pranata Edu, 2(1), 33-39.

Marbun, P. (2021). Disain Pembelajaran Online Pada Era Dan Pasca Covid-19. CSRID (Computer Science Research and Its Development Journal), 12(2), 129

Nur, Annisa. (2020). "Pemanfaatan Aplikasi Zoom Sebagai Media Pembelajaran Di IAIN Kota 
Sorong." ResearchGate, doi:10.13140/RG.2.2.14759.98724.

Pechenik, Jan A. (2010). Biology of The Invertebrates. 6 edition. New York: McGraw-Hill.

Putri Zakiyatul Zannah, Diah Mulhayatiah, Fathiah Alatas. (2014). "Penggunaan Media Pembelajaran Zooming Presentation Untuk Meningkatkan Hasil Belajar Siswa Kelas X Pada Konsep Suhu Dan Kalor." EDUSAINS, 04(02).

Riyadi, \& Larasaty, P. (2020). Masyarakat Pada Protokol Kesehatan Dalam Mencegah Penyebaran Covid-19. Seminar Nasional Official Statistics 2020:Pemodelan Statistika Tentang Covid-19, 19, 45-54.

Rosyid, N. M., Thohari, I., \& Lismanda, Y. F. (2020). Penggunaan Aplikasi Zoom Cloud Meetings Dalam Kuliah Statistik Pendidikan di Fakultas Agama Islam Universitas Islam Malang. Jurnal Pendidikan Islam, 5(11), 47-52.

Sadikin, A., \& Hamidah, A. (2020). Pembelajaran Daring di Tengah Wabah Covid-19. BIODIK, 6(2), 109-119.

Sadiman AS, Raharjo R, Haryono A, Rahardjito. (2011). Media Pendidikan: Pengertian, Pengembagan, Dan Pemanfaatan. Jakarta : Rajawali Pers.

Setiani, A. (2020). Efektivitas Proses Belajar Aplikasi Zoom Di Masa Pandemi dan Setelah Pandemi Covid-19. Efektivitas Proses Belajar Aplikasi Zoom Di Masa Pandemi Dan Setelah Pandemi Covid-19. Prosiding Seminar Nasional Pascasarjana UNNES 